Article

\title{
THE EU, RUSSIA AND CYPRUS
}

\author{
Andreas Stergiou*
}

DOI 10.24833/2073-8420-2019-4-53-56-68

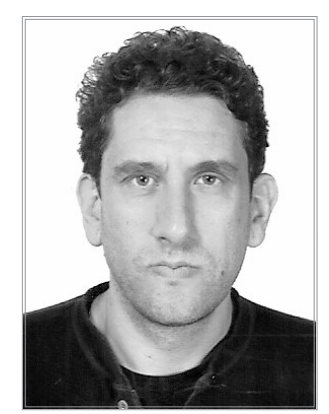

In recent years, Russian-Cypriot relations have been a very topical issue among EU politicians, scholars and journalists dealing with international relations of Russia, South-eastern Europe and the Eastern Mediterranean. Through this deep interest many unknown parameters of the topic have been illuminated. Nevertheless, most of the analyses followed a certain pattern that did not always dovetail with reality. Although Cyprus has possessed an exceptional place in the Russian foreign policy, Russia's interest in the Cypriot economic and political affairs, however, have been in some cases overrated. As a result, for various geo-political and geo-economic reasons the island has been dragged into the EU-Russia political and economic troubled NATO-EU-Russia relationship of the last decade and paid a high tribute for it. Against this background, it is argued that the Eurogroup's decisions regarding the Cypriot banks in March 2013 were groundless and false and eventually backfired on the goals they intended to achieve. The article also counter-argues the opinion that Moscow is interested in the EastMed gas reserves because of their value in the EU-energy supply diversification policy. Russian companies do not seem to oppose the various projects aimed at exploiting EastMed resources, as they do not view East Med gas as a threat to their economic interests.

\section{The Historical Background}

${ }^{y}$ yprus has over the decades been a key component of Kremlin's policy in the region and an apple of discord within the Western powers, not only because of its strategic importance. During the Cold War the Soviet Union maintained a consistent policy of engagement in relation to Cyprus with a view of weakening the island's ties with the West and extending Soviet influence southward. Kremlin's course can be identified as a policy of "fishing in muddy waters", i.e. a slow but steady penetration into Eastern Mediterranean countries. This penetration was achieved mainly through indirect tactics. Rather than making territorial demands and sending in armed forc- es to annex, the Soviets, similarly to their allies, supported various political groups and governments with a view to weaken ties with the West and extend Soviet influence southward. More precisely, they supported various Cypriot political and social groups and movements, which were in favour of a nonaligned policy for the Island Republic (in an independent Cyprus Communism would have many more possibilities to grow). For this reason, Moscow has traditionally declared its commitment to safeguarding Cyprus's State sovereignty and neutrality in order to avoid the pro-NATO militarisation of the island. Nevertheless, the support never went beyond equivocal and diplomatic statements calling for a peaceful resolution of the conflict and active involvement of

\footnotetext{
* Andreas Stergiou, Associate Professor at the Department of Economics, University of Thessaly (Greece) e-mail: snandreas@econ.uth.gr ORCID ID: 0000-0002-8055-9298
} 
the United Nations ${ }^{1}$ through the unrealistic option of the convocation of a broad international conference on the issue ${ }^{2}$.

Following the coup d' état and the ensuing Turkish invasion of Cyprus in August 1974 a fierce anti-American, anti-Western and often slightly pro-Soviet propaganda in the post-dictatorial era in Greece and Cyprus propagated the unexamined assumption that NATO was responsible for the Turkish occupation of Northern Cyprus. ${ }^{3}$ NATO, however, was not empowered to act beyond its accepted remit and against an alliance member, like Turkey, to protect a nonalliance member, like Cyprus, which happened to also be a leading member of the relatively anti-Westernnon-aligned movement. However, according to newly revealed, declassified information, Henry Kissinger, US Secretary of State at the time, seems to have backed the Turkish invasion. In this respect, Kissinger is supposed to have told the thenUS President Gerald Ford that Turkey was entitled to seize part of the island, confirming what, to some degree, many historians have asserted about US Secretary of State's involvement in the affairs of the island in the summer of $1974 .{ }^{4}$

The European Community's prestige in Cyprus was also somehow overshadowed by the dominant anti-NATO feelings, not only because of the fact that most of the EC-members were simultaneously NATO-members, but also because the European Community's (EC)reaction to the Turkish invasion was not considered satisfactory. The declaration issued by the EC in the framework of the European Political Cooperation reflected mainly the UK's attitude to the dramatic events. It expressed generally member-States' concerns over the tension in the region, their support of the independence and integrity of the island and their opposition to any intervention and interference, while avoiding to condemn Turkish actions. ${ }^{5}$ Since then, the European Community followed a rather impar- tial course by encouraging negotiations between the Greek and the Turkish Cypriots, avoiding to present any concrete plan of mediation and merely expressing its moral support for the mediation mission of the UN Secretary General. ${ }^{6}$

With the aforementioned in mind, one can conclude that the European Community did not live up to the strategic considerations that had dictated the signing of the Association Agreement between the Republic Cyprus and the European Economic Community in 1972. From a European point of view, the EC had little to gain economically from Cyprus at that time, but at the same time it was important to attain political stability in the region. The strategic importance of Cyprus as a bridge to the Middle East overrode any economic argument. ${ }^{7}$

In turn, official Cypriot-Russian relations date back to the 1960's when the USSR established diplomatic relations with the newly independent Republic of Cyprus. In 1982, the two States signed a waiver-agreement of double taxation that was very taxpayer-friendly, providing for zero withholding taxes on dividends, interest, and royalties. As a result, at the beginning of the 1990s, Cyprus was one of the few capitalist countries with an institutional framework for Russian capital outflows and inflows already in place. The 1982 double taxation agreement also adopted by most of the former members of the Soviet Union after gaining independence. Western investors were familiar with Cyprus's legal and commercial infrastructure, based on the common law legacy left by the UK, the former colonial power and had far more confidence in it than in the evolving and initially unreliable legal systems of the newly marketised countries. As a result, Cyprus did not become only one of the favoured destinations for Russian capital but also the preferred jurisdiction for holding and finance investment structures from the West into Russia and Eastern Europe, providing stability, predictability, transparency, and tax

1 Moscow and its allies also supported Greece's efforts to achieve the self-determination of Cyprus at the United Nations in the 1950s, against London's and Washington's orchestrated opposition.

2 A. Stergiou (2007), 'Soviet policy toward Cyprus', Cyprus Review, Vol. 19, No. 2, 83-106.

3 This actually echoes the official Kremlin public pronouncement of 6 July1967 on the Greek military Junta. Th., Adams and A. Cottrell, Cyprus between East and West. (Baltimore: The John Hopkins University Press, 1968), 5051.

4 The National Herald (Staff), 'White House 1974 Cyprus Meeting: Kissinger Backed Turkey Over Greece', September 4, 2018, https://www.thenationalherald.com/212131/white-house-1974-cyprus-meeting-kissinger-backed-turkeyover-greece/

5 Auswärtiges Amt der BRD, Europäische Politische Zusammenarbeit. Dokumentation. (Bonn: Auswärtiges Amt der Bundesrepublic 1987), 87

6 Ch. Tsardanidis, 'The European Community and the Cyprus crisis of 1974', Revue Hellénique de droit international, Vol. 5 (1984), 185-207.

7 G. Christou, The European Union and Enlargement. The Case of Cyprus. (New York: Palgrave Macmillan, 2004$), 63$. 
savings. Over the ensuing two decades, Cyprus consolidated its position as the portal of choice for investment between Russia and Eastern Europe and the rest of the world. ${ }^{8}$ Moreover, from the early 1990's onwards, Russians were among the most active non-resident portfolio investors to the Cyprus Stock Exchange with the overwhelming majority of the invested money deriving from Russian capital ${ }^{9}$.

Cyprus' accession into the European Union in 2004, albeit it induced a wave of legislative changes, did not halt this trend. In October 2010, the two countries signed a new bilateral agreement (Convention for the Avoidance of Double Taxation of Income and Property) to avoid double taxation, which further increased the flow of investment. The common characteristic of all double tax treaties Cyprus signed, is that they all reduce or eliminate the usual withholding taxes imposed by the contracting states on dividends, interest and royalty payment. Cyprus does not impose withholding tax on payments of dividend, interest and royalties paid by international business companies. Therefore, a Cypriot international company is more likely to receive dividend interest, royalties and capital gains from another treaty country, so that the withholding tax is reduced. The interest and royalty payment is in most cases a deductible expense in a high tax jurisdiction, whereas the capital gain is tax exempt. Cypriot private capital was also a major investor in the Russian securities market. These investments were often considered the inflows of Russian capital. To a large extent these outbound investments acted as safety nets for Russian companies to protect themselves from political uncertainties in the domestic environment. However, the forthright position of Cyprus in Russian economic affairs may also indicate that many foreign companies wishing to trade with Russia used Cypriot subsidiaries in order to take advantage of the favourable taxation in Cyprus. This increased capital circulation captured the attention of various observers, who estimated that money laundering and tax evasion were the main driving forces behind capital movements ${ }^{10}$.

Gradually, the island's reputation evolved towards of being the money laundry hub of the Mediterranean, a haven for Russians and Serbians escaping political turmoil and a magnet for capital flows, which are then channelled to the Russian economy. Therefore, some observers deem Cyprus as a "weak link" in Europe's banking system because of its lax approach to questionable Russian money that allegedly 'pose a threat to other countries' banks in the single market and created hazards for European democracy'11.

There are still numerous Russian companies based in Cyprus, though notably many of them are show business, despite the pressure on Russian companies to repatriate assets. Most of them are located in Limassol, where a sizeable Russian-speaking community lives and Russian schools, Orthodox Churches, Russian-language television and radio services have been founded. Cypriot law permits non-residents who acquire property with a minimum sale price of EUR300,000to claim permanent residency rights, while those who spend EUR5 million or more on property can apply for passports. Other entities, such as the Cyprus-Russia Business Association, established in 1996, and the Business Council for Co-operation with Cyprus, established in 2011, aim at fostering and expanding economic and trade relations between Cyprus and Russia. Russian oligarchs who have been granted Cypriot citizenship have created a new political party in Cyprus, called "Me the citizen", which supports further UN talks on the future of the divided island and aims to take part in the upcoming European elections in 2019. The

8 E. Neocleous (2015) 'The potential impact of Russian de-offshorization legislation on Cyprus holding and finance structures', Trusts \& Trustees, Vol. 21, No. 6, 610-613.

9 Central Bank of Cyprus, Monetary Policy Report, 2002, http://www.centralbank. gov.cy/nqcontent.cfm?a_ id=10364\&lang=en, accessed 3 April 2017

${ }^{10} \mathrm{~K}$. Liuhto (2001) 'Russian gas and oil giants conquer markets in the West: Evidence on the internationalization of Gazprom and LUKoil', Journal of East-West Business, Vol.7, No. 3, 35; K. Liuhto and S. Majuri (2014) 'Outward foreign direct investment from Russia: A literature review', Journal of East-West Business, Vol. 20, No. 4, 199-200; E. Pelto, P. Vahtra, K. Liuhto, Cyprus Investment Flows to Central and Eastern Europe - Russia's Direct and Indirect Investments via Cyprus to CEE. (Turun Kauppakorkeakoulu: Turku School of Economics and Business Administration, 2003), 11-16; N. Fabry and S. Zeghni (2002), 'Foreign direct investment in Russia: How the investment climate matters', Communist and Post-Communist Studies, Vol. 35, No. 3, 293-294; P. Phidias, The Role of Cyprus in Inward Investment in Russia, Central and Eastern Europe. (Cyprus: PricewaterhouseCoopers, 2002), 6.

${ }^{11}$ A. Rettman (September 2018), 'Cyprus: Russia's EU weak link?', EU Observer, https://euobserver.com/ justice/14292025; European Parliament Press Releases, 'Tax crimes: special committee calls for a European financial police force', February 27, 2019, http://www.europarl.europa.eu/news/en/press-room/20190225IPR28727/taxcrimes-special-committee-calls-for-a-european-financial-police-force 
leader of the party is Alexey Voloboev, a businessman from Limassol who owns a radio station in Cyprus.

\section{The EU-Russia Defence and Political Tug-of-War Around Cyprus}

After Cyprus recognised Russia as the successor to the USSR in 1992, the defence cooperation between the two countries flourished. Since the Republic of Cyprus has not been constrained by any alliance restrictions (NATO for example) and given the US arms-embargo on Cyprus until today, there were only two obstacles to the acquisition of Russian arms: the Turkish reactions and the British objections. The latter derived from the presence of the two Sovereign Military bases of the UK on the island under the terms of the 1960 Treaty of Independence. The first Russian-Cypriot agreement on military technical cooperation was signed in March 1996. During the period 1991-2011, the Russian Federation and the Republic of Cyprus concluded EUR430.5 million of deals for the purchase of Russian military hardware. Especially, after the 1996 agreement, Nicosia began to purchase Russian weapons, including 43 BMP-3 and 41 T- $80 \mathrm{U}$ tanks as well as 6 Tor-M1 surface-to-air missiles (SAM) systems. During the 2000s, Cyprus bought 4 BM-21 Grad self-propelled multi-rockets launchers, $12 \mathrm{Mi}-24 \mathrm{P}$ combat helicopters, 3 Mi-8MT helicopters, and an additional lot of 41 T-80Us in $2010^{12}$.

The acquisition of the S-300 January 1997 anti-aircraft turned out to be a source of trouble for Cyprus. Both Washington and Ankara strongly reacted against the installation of the S300 missiles on the island. Washington was concerned that the deployment of S300 missiles in Cyprus would bring the Eastern Mediterranean under Russian control and it exerted pressure over Athens and Nicosia to cancel the ac- quisition of the missiles, repeatedly statingthat this action would not contribute to stability and thus would constitute a seriously troubling factor. According to the declassified presidential records which former US President Bill Clinton recently made public, he was very bothered by the deal and regarded it as a "terrible" development because of the "Russian connection" and hence asked Tony Blair to apply pressure on Cypriot President Glafkos Klerides to stop the delivery of the missiles. ${ }^{13}$ After more than two years of a diplomatic tug-of-war, the Greek and Cypriot Government finally bowed to US pressures and made a retreat. ${ }^{14}$ The missiles were bought but installed in Crete instead of Cyprus in September 1999, where they were first tested 14 years later!

This harmonious defence cooperation was also reflected on a political level. In April 2004, during a very important session of the UN Security Council on the future of Cyprus and in a climate of great expectation coupled with uncertainty, Russia was the only country torpedoing a UN resolution. That resolution should provide sufficient security guarantees for the implementation of the so-called Annan Plan that had been proposed by the UN Secretary General. The respective plan was strongly supported by the US and the UK with the aim to precipitate a "pro-western" solution in the Cyprus problem. In this case Putin's Moscow successfully dealt a diplomatic blow exploiting rivalries between the Western states involved in the Cyprus Improglio. The vehicle for the materialisation of the gambit was an old Moscow ally, the powerful Cypriot Communist Party-AKEL. Many of the party's high-ranking members studied in Moscow or in other former socialist countries. By seeking an alibi to reject the plan, the party had persistently demanded for further security guaranties before the plebiscite which the UN Security Council resolution was supposed to offer ${ }^{15}$.

12 T. Zonova (2015) 'Mediterranean trend in the Russia's foreign policy', Rivista di Studi Politici Internazionali, Vol. 82, No. 4, 525-526; I. Delanoe (2013), 'Cyprus, a Russian foothold in the changing Eastern Mediterranean', Middle East Review of International Affairs, Vol. 17, No. 2, 88.

${ }^{13}$ US Department of State, Daily Press Briefing, 28 August 1998; Clinton Presidential Records, declassified documents, Memorandum of Telephone Conversation between Bill Clinton and Tony Blair, 11 December 1998, 238. https://www. clintonlibrary.gov/

${ }^{14}$ Ch. Tsardanidis and Y. Nicolaou, 'Cyprus Foreign and Security Policy: Options and Challenges', in: The Foreign Policies of the European Union's Mediterranean States and Applicant Countries in the 1990s, eds. S. Stavridis, T. Veremis, T. Couloumbis, N. Waites. (Basingsstoke, Hampshire, University of Reading European and International Studies, 1998), 181-182.

${ }^{15}$ A. Stergiou, 'Russian Federation's Foreign Policy in the Eastern Mediterranean Since the End of Cold War: Geoeconomic and Geopolitical Parameters', in: Conflict \& Prosperity, Geopolitics and Energy in the Eastern Mediterranean, eds. Andreas Stergiou, Kivanc Ulusoy and Menahem Blondheim (New York-Jerusalem: Konrad-Adenauer-Stiftung - The Harry S. Truman Research Institute for the Advancement of Peace Hebrew University of Jerusalem in cooperation with Israel Academic Press, 2017), 89-90. 
In return, Cyprus has become an ardent voice for Russia within the European Union and is considered as one of Moscow's most reliable allies in the bloc. During the Russian-Georgian conflict of August 2008, the former Cypriot President was among the few international leaders and the only EU member-state leader to support Russia. Later, he also backed Moscow's demands on the US missile defence system in Eastern Europe ${ }^{16}$. In July 2016 the parliament voted, 33 in favour with 17 abstentions, a resolution to lift sanctions against Russia ${ }^{17}$.

Moreover, the Republic of Cyprus tried to build bridges between the Union and the Russian Federation. For example, Markos Kyprianou, serving as EU Health Commissioner, sought to mediate a particularly acrimonious dispute between Russia and Poland over meat exports that threatened to derail a new EU cooperation agreement with Russia. As very experienced scholars have pointed out, the example of Cyprus highlights in many ways the degree to which the perception that Russia opposes EU membership for states that it believes are friendly is in fact incorrect. In fact, it is significantly more beneficial for Russia to have champions like Cyprus within the $\mathrm{EU}^{18}$.

AKEL's Cold-War resentments have motivated the country's anti-NATO stance, which has notably been in favour of Russia's interests. While membership of NATO is not a requirement for EU membership, most EU members are part of the alliance. As of 2004 Cyprus and Malta have been the only two EU entrants that are not members of the organisation. This status quo has rendered the Cyprus Conflict to the most intractable issue within the EU and NATO. Turkey, an EU applicant is a leading NATO-member which does not recognise the Republic of Cyprus. Cyprus, in its turn, is an EU but not a NATO-member. Furthermore, Turkey has denied the use of its sea and airports to Greek Cypriot ships and aircraft. Also, Ankara has prevented the participation of Cyprus in high-level formal meetings between NATO and the EU-Political and Security Council and obstructed discussions over military operations and intelligence issues, all on the ground that Cyprus did not possess any security clearance from NATO ${ }^{19}$.

Notably, those EU members, officially maintaining a policy of neutrality in their external relations, have opted to join the Partnership for Peace. Because of AKEL's resolute objections, Cyprus has been the only country choosing to go down a different path despite increasing reactions by all the other political parties. The party also feels that Russia, contrary to the US and the European Union, plays a positive role in the region. Cypriot Communists' view, as expressed in surveys, is that the US strategy in the Middle East, in conjunction with the EU's "European Security Strategy", has provoked the violent redrawing of borders in that region and the overthrow of non-cooperative governments. In AKEL voters' view, the bloody civil war raging in Syria and the millions of Syrians becoming refugees is the result of US-NATO-EU-Turkey- Gulf monarchy policies to overthrow the Assad government ${ }^{20}$.

These views are not confined only in the Cypriot leftist political spectrum. It is a commonly held perception that the strongest immediate condemnation of Turkey's violations of Cyprus' sovereign rights in the Mediterranean came from Moscow, while Washington and Brussels maintained a rather neutral attitude, while encouraging Ankara to raise claims on "the sharing of discovered hydrocarbons in the Cyprus Economic Exclusive Zone" ${ }^{21}$.

The discoveries of gas deposits south of $\mathrm{Cy}$ prus since 2011 and its potential impact on the EU's energy diversification policy, e.g. making East Mediterranean gas a viable alternative to Russian gas, thereby lessening EU's dependence on Russian gas imports, have nurtured various theories about Kremlin's strategy on Cyprus. For example, towards the end of 2016 the Cypriot local press repeatedly reported that Russian officials had attended anti-unification political gatherings, whilst there is evidence that Moscow might be using social and mass media, as well as ties to fringe nationalist political parties

${ }^{16}$ Delanoe, op. cit., 88

17 D. Bechev, Rival power. Russia's influence in Southeast Europe. (New Haven and London: Yale University, 2017), 132.

18 J. Ker-Lindsay, 'Membership and Foreign Policy', in: An Island in Europe. The EU and the Transformation of Cyprus, eds. J. Ker-Lindsay, H. Faustmann and F. Mullen. (London and New York: Tauris, 2011), 124-125.

${ }^{19}$ A. Stergiou, 'The History of Cyprus', in 'The Middle East and North Africa', ed. Christopher Matthews. 65th edition (London and New York, Routledge, 2019), 160-161.

20 S. Dennison \& D. Pardijsp, 'The world according to Europe's insurgent parties: Putin, migration and people power', European Council on Foreign Relations Paper (June 2016), 4, 11.

${ }^{21}$ C. Melakopides, Russia-Cyprus Relations. A Pragmatic Idealist Perspective. (Basingstoke, Hampshire: Palgrave Macmillan, 2016), 126-152. 
and the Greek Orthodox Church, to undermine the settlement talks. Some analysts linked this interference to the energy competition, arguing that the Western countries' strategy to prepare the ground for an energy deal aimed at loosening Europe's dependence on Russia, prompted this particular reaction from Moscow ${ }^{22}$.

As a matter of fact, although the evidence of direct intervention to prevent Cypriot reunification is scant, it is likely that Russia is not interested in a final settlement. This is not associated with the gas finds, not only because the EastMed deposits do not constitute a serious threat to Gazprom's dominant position in Europe but also because they have had a very limited impact on the negotiations.

People consistently involved in the exploration of the hydrocarbons ${ }^{23}$ admitted that the energy deposits did play a certain role in the conflict, but they were not decisive to the same extend with other political and geopolitical parameters. According to Andreas Mavrogiannis, a Cypriot diplomat and special negotiator of the Republic of Cyprus in the inter- communal talks since 2013, the prospect of significant energy wealth in the Eastern Mediterranean affected the US policy vis-a-vis Cyprus. The US have indeed attempted to use the prospective natural resources in order to achieve: a) the solution of the Cyprus issue, b) the restoration of the bilateral Turkey-Israel relations, c) the creation of a new framework of economic cooperation in the Eastern Mediterranean to the best interest of the US and the UK, which might also include the exclusion of Russia from the energy exploration in the Eastern Mediterranean. However, he categorically dismisses the allegation that Russia undermined the efforts for a solution or blocked the process. On the contrary, according to Mavrogiannis, Russia has been steadily promoting a solution of the Cyprus issue and opposed Turkey gaining control over Cyprus, not for idealistic reasons but because such a development would run against to the Russian goals in the region. Misalignment with NATO and a positive stance towards Russia is Moscow's preferred status of Cyprus. Russia has also been opposing Western security guarantees and has been instead arguing for a full demilitarisation of the island. That is why, it is also seeking to diminish the British military presence. As other experts have suggested ${ }^{24}$, Russia does not consider the Eastern Mediterranean deposits as a significant threat to its own deposits and therefore has not displayed any particular interest to participate in their exploration.

To be precise, Russian companies have demonstrated some interest in the EastMed natural gas resources. In December 2016, the Russian State company Rosneft bought a 30\% stake in Egypt's Zohr gas field from Eni, with the consent of the Italian government, making the Russian company the second largest stakeholder in Zohr. That is another case where Russian companies acquire a stake in resources, which could threaten to undercut their dominance in the European markets. The official reason for the sale was the need for Eni to spread the risk of its Egyptian operation. Similarly, offshore gas discoveries in Lebanese waters have attracted Russian interest. Russia's private company Novatek has already bought a $20 \%$ stake in a block, whereas Russia has also reserved a contract for future gas exploration in Syria. In Iraq, Russia is involved in pipeline deals in the Northern Iraq region through a number of oil and gas companies, although the actual exports would have to pass through Turkish territory or possibly even through Syria in the distant future ${ }^{25}$. Russia has also expressed interest in developing Block 9. Negotiations over the development of Block 9 between a consortium led by the French company Total, the Russian Novatek and GPB Global Resources-the latter belongs to Gazprom- collapsed in December $2012^{26}$.

Nevertheless, Moscow does not seem to oppose the various projects aimed at exploiting East Med resources. Economic and political elites do not view EastMed gas as a threat to their economic interests, as they do not fear any serious threat to their dominant position as Europe's energy provider. None of the Rus-

\footnotetext{
${ }^{22}$ S. Stefanini, 'Cyprus fears Russia could wreck reunification', Politiko, 17 February, 2017, http://www.politico.eu/ article/cyprus-fears-russia-could-wreck-reunification/; K. Tastan and T. Kutschka, 'The Implications of Eastern Mediterranean Gas for Turkey', The German Marshall Fund of the United States paper, no. 7. (2019), 2: Bechev, op. cit, p. 135.

${ }^{23}$ Personal Communication with Andreas Mavrogiannis, (electronically, August 2017).

${ }^{24}$ Personal Communication with Kavus Abushov, Professor at Azerbaijani Diplomatic Academy-ADA, Expert on Russia (Baku, 22 August 2017) and Yuri Kvashnin, Head of Section of the EU Studies of the Institute of World Economy and International Relations of the Russian Academy of Sciences, (Moscow, 3 September 2015).

${ }^{25}$ M. Pierini, 'Russia's Gas Strategy Gets Help From Turkey', Carnegie Endowment, 3 December, 2018 https:// carnegieeurope.eu/strategiceurope/77855

${ }^{26}$ Delanoe, op. cit., 88.
} 
sian companies has participated in the international tenders of Israel and Cyprus. The reasons for this are economic rather than geopolitical ${ }^{27}$.

The exploration costs in the Eastern Mediterranean are quite high, the competition with other international companies is fierce and the export and transportation costs are also significant. Though it is very difficult for Gazprom to dump or to lower international gas prices, in order compete with EastMed gas or to halt LNG exports or imports from the US, it is not impossible. This lies on the world gas delivery structure. There are more short-term gas contracts indexed in the spot market and fewer on long term contracts with take or pay clauses. Gazprom's policy is based on long term contracts with take or pay clauses ${ }^{28}$.

The rapid increase, however, of the US. LNG exports (based on the shale gas revolution the US is poised to become the largest LNG exporter by 2025) (along with increased capacities in Qatar, Australia, Russia, Canada and other countries) has the potential to disrupt global gas trade patterns and dramatically transform the European market over the next two decades. US LNG exports could also reduce Europe's dependence on Russian gas, even while Moscow increases subsidies for gas exports to Europe. The slash in Russia's gas export revenues has already forced its gas companies to renegotiate contracts with much shorter and more flexible terms. Energy experts estimate that, if the US increase exports to Europe, Russia might be forced to raise subsidies and lower prices even further. Gas prices in Europe could come under downward pressure $^{29}$.

During the past years Gazprom has adapted itself to the new realities of the European market. The granting of discounts, partial revision of long-term contracts, inclusion of spot prices when pricing long-term contracts and retroactive compensation of "additional" payments to consumers have allowed Gazprom to preserve its share in the European gas market. Still, these developments were predominantly driven by market forces, and less by strategic moves against Russia. Therefore, the sanctions imposed by the West in relation to the Ukrainian crisis have not caused any particular disruption in the functioning of the energy sector in the short- and mid-term perspective ${ }^{30}$.

Regardless of the energy issue, from 2012 onwards there has been a massive Russian naval presence in the Eastern Mediterranean, mainly due to the civil war in Syria that appears to complicate the once unrestrained capacity of NATO and the American 6th Fleet to ensure freedom of manoeuvre in the region. Both EU and NATO countries now find themselves within striking distance of Russia's shiplaunched cruise and ballistic missiles. Furthermore, Russian surveillance and electronic warfare assets can now be legally and regularly deployed close to NATO, accessing stations in Turkey and the British Royal Air Force (RAF) base in Akrotiri Cyprus, further compromising NATO's long-held advantage in intelligence collection and electronic warfare. The Alliance thus finds itself in a vulnerable position during a time of upheaval in the Eastern Mediterranean ${ }^{31}$.

In this regard Moscow's decision in February 2015, to provide debt relief to the Republic of Cyprus, restructuring the EUR2,5 billion bailout loan it had given Cyprus in 2011 (see further down) seems to be directly linked to the access the Kremlin obtained to Cypriot ports for its naval vessels in 2015 with the aim of counterfighting terrorism and piracy and despite US' opposition $^{32}$.

\footnotetext{
${ }^{27}$ Personal Communication with Yuri Kvashnin, Head of Section of the EU Studies of the Institute of World Economy and International Relations of the Russian Academy of Sciences (Moscow, 3 September 2015) and Kavus Abushov, Russia expert, Professor of Political Sciences at the ADA University (Baku, August 2017).

${ }^{28}$ Personal communication with Dr. Amit Mor, Energy Expert-Professor for Energy economics and geopolitics (September 2018, Hertzliya, Israel).

${ }^{29}$ F. Umbach, 'The future of LNG for Europe', Geopolitical Intelligence Service, March, 18 2019, https://www. gisreportsonline.com/the-future-of-Ing-for-europe,energy,2829,report.html

30 N. Kaveshnikov, 'Energy security in Mogherini' s strategy: Conclusions for Russia', in: The EU global strategy: implications for Russia, ed. Olga Potemkina (Moscow: Institute of Europe, Russian Academy of Sciences/Egmont. The Royal Institute for International Relations, 2017) 53-55.

${ }^{31}$ V. Kappis (2016) 'The Bear Learns to Swim: Russia's Re-emergence in the Mediterranean', Eastern Mediterranean Geopolitical Review, Vol. 2, 42.

${ }^{32}$ Alterman J. B., Conley H. A., Malka H., Ruy D., "Restoring the Eastern Mediterranean as a U.S. Strategic Anchor", Center for Strategic and International Studies (CSIS) report (New York et. al.: Rohman and Littlefield, 2018), 5-8; O. Razumovskaya, 'Cyprus signs deal to let Russian navy ships stop at its ports'. Wall Street Journal, Feb. 25, 2015. http://www.wsj.com/articles/putin-highlights-closer-russia-cyprus-ties-1424882012
} 


\section{The EU-Stance on the Russian-Cypriot Economic Ties}

In 2011, Cyprus experienced significant difficulties due to the debt crisis in Greece, to which the island is closely economically linked. Despite the fact that Cyprus was unable to pay the bonds worth around USD1.2 billion in early 2012 without external financial assistance, in August 2011, the European Commission announced that it would not allocate credits to Cyprus, similar to those previously issued to Greece in the context of a bail-out programme. As Cypriot banks - the fundamental pillar of the island's economy-were heavily exposed to the Greek sovereign debt and significant rescue funds were required to shore them up, credit rating agencies dramatically lowered Cypriot debt rating to junk status. Since Cyprus was then effectively excluded from international markets, the communist-at that time-government in Nicosia, with strong ties to Russia since the time of Cold War, sought help from Russia, which granted Cyprus a loan of USD2.5 billion. However, this loan was not enough to enable the government to shelter the island's economy for the repercussion of the debt crisis in Eurozone. The haircut in Greek government debt in the spring of 2012 brought about heavy losses in Cypriot banks, forcing the government in Nicosia to seek fresh capital in order to recapitalise the island's banking sector. As it was still excluded from the bond markets, Nicosia turned again to its partners in the European currency union for financial aid, considering itself unfairly treated by the EU decision to restructure Greece's debt, as it had coerced Cypriot banks into writing off around 80\% of the value of their Greek bond holdings.

Nevertheless, the new load-provider scheme, consisting of the European Central Bank, the European Commission and the International Monetary Fund, known as the Troika, was willing to grant that assistance only in the context of a bailout programme, which entailed much stricter conditions -as demanded by other EU countriesthan the loan it had so far taken from Moscow. As a result, Nicosia decided to turn again to Moscow asking for a further EUR5 billion loan. Moscow, however, refused to lend more money to Cyprus, which accordingly turned back to its European partners for financial assistance. The feeling was that the "Russia card" had been merely a diplomatic manoeuvre used by the authorities in Nicosia in their negotiations with the European Union ${ }^{33}$.

The EU found itself in a dilemma: either fund the bailout itself in full, which means coming up with the USD17 billion needed to bail the troubled banks of the island out or force a haircut on their depositors. It opted for the second choice. On 15 March 2013, the Eurogroup ministers agreed a EUR10 billion deal with Cyprus, which included austerity measures, significant reforms in the banking and public sector to be supervised by the European Commission, the European Central Bank and the IMF, as well as a limited bank levy on all deposits, even the smallest ones. Against a background of huge public outcry and demonstrations outside the House of Representatives, the deal was rejected. On 25 March a new plan was announced to preserve all insured deposits of EUR100,000 or less without a levy, but shut down Laiki Bank, the second largest bank in Cyprus, levying all uninsured deposits there, while levying up to $60 \%$ of uninsured deposits in the Bank of Cyprus (the largest bank on the island). The Eurogroup's decisions precipitated a blow the Cyprus' economic model and provoked fear, uncertainty and bitterness among Cypriot political forces and citizens, as they badly hit the island's thriving service sector endangering the country's status as tax haven and spreading for the first time strongly negative images of Europe ${ }^{34}$.

In fact, in spring 2013, the bail-out became a bail-in agreement imposed by an informal, coordinating EU-institutional body, the Eurogroup. According to the official statements of that time, this attitude was an early test of what has since become the official European Union policy of "bailing in banks" intended to force creditors and depositors to pay for a bank's mistakes and to spare taxpayers from paying for their rescue. In the pre-crisis period, Cyprus' financial sector had grown to dwarf the rest of the Cypriot economy, accounting for about eight times the country's annual gross domestic product and employing a substantial portion of the nation's work force. As a consequence, when the financial sector experienced problems, the state fiscus

33 J. Manuel, P. Triana, 'Russia in the Eastern Mediterranean: a counterweight to the West?', in: War in peacetime Russia's strategy on NATO's Eastern and Southern Flanks, eds. N. De Pedro and F. Ghilès (Barcelona: Barcelona Institute for International Affairs, 2017), 46.

${ }^{34}$ A. Stergiou, 'Euroscepticism in Cyprus', in: European Integration and New Anti-Europeanism. The 2014 European Election and New Anti-European Forces in Southern, Northern and Eastern Europe (volume 2), eds. P. Moreau \& B. Wassenberg (Stuttgart: Franz Steiner, 2016), 56-58. 
was not big enough to stabilise the banks without external help. At the time, there was a widespread belief - also literally expressed by some European politicians- that the Cypriot banks model was faulty and so a reduction of its size was necessary to balance things out and bring the banking sector to a more sustainable level. Moreover, due to the perception that a large chunk of the deposits was of questionable origin, the Eurogroup decided for first time to take a hard line with the country ${ }^{35}$.

A little later the source of this perception was revealed: a confidential report by the German intelligence service (Der Bundesnachrichtendienst - BND), had painted the island a few months ago as a haven for money-laundering. According to the leaked report of the German Intelligence Service, Russians had, at the time, as much as EUR21billion in suspicious funds ${ }^{36}$.

However, it seems that other political, geoeconomic and geo-strategic factors have codetermined Troika's course towards the Cypriot economy. The total amount requested was EUR17,5 billion, a mere pittance compared to the sums of the previous bailout packages of Greece, Ireland, Portugal and Spain. The argument was put forward at the time that Cyprus' banking sector is tiny relative to the rest of Europe; one Cypriot bank defaulting and as a result putting the whole European banking system in question, can be hardly regarded as tenable. The assumption that a great deal of Russian oligarchs has traditionally used Cypriot banks for money laundering and tax avoidance seems to be devoid of real tangible evidence. The potentially criminal nature of the Russian deposits cannot be denied totally; however, it was overemphasised to downplay the effect on ordinary law-abiding Cypriots and Russians. At that time, Germany, which would carry much of the financial burden and was preparing for elections in September 2013, was reluctant to shore Cypriot banks up before an electorate that was increasingly hostile to bailouts. Cypriot financial institutes paying high interest to Russian depositors, when the Germans were receiving a nominal interest rate below inflation, was also taken as an affront by the leading economic force of the Eurozone and most important decision-maker of the Eurogroup. It is also very likely that Cyprus was utilised to set a warning example to Moscow because of its growing military footprint in the Eastern Mediterranean, its alleged or real meddling in Cypriot domestic political affairs and its involvement in Syria war.

If the BND-report was truly the driving force behind the Eurogroup's fatal decision, it is a real mystery the information and sources the German agents used to make this allegation. According the statistical data compiled and published by the Central Bank of Cyprus since the adoption of euro in full compliance with the legal framework of the European Central Bank ${ }^{37}$, in March 2013, the month the haircut was conducted, the total amount under 'Residents of rest of the world' (meaning residents of countries other than Cyprus and other EU Member States belonging to the euro area) was EUR19,035.4 million, while the total amount of the deposits was EUR63,716.4 million. That means that even by making the arbitrary assumption that all the foreign money deposits belonged to Russian (it is widely known that big sums of Arab capital are deposited in Cypriot banks as well), the number is still below the figures reported by the German agency. Also, according to Eurostat ${ }^{38}$ - the official statistics service of the European Union- the total deposit taking corporations except for the Central Bank, coming from Russia amounted to EUR16,901 million in the first quarter of 2013, just before the levy was imposed.

Further, according to the report by the committee of experts on the evaluation of antimoney laundering measures and the financing of terrorism (MONEYVAL), at least until 2011, the Cyprus bank business system was perceived to cope with all the anti-money laundering and the criminalisation of the financing of terrorism standards. Nonetheless, it was targeted over night as a money-laundering machine ${ }^{39}$.

\footnotetext{
${ }^{35}$ P. Tilliros, 'Causes and impact of the MOYs on the economies of Cyprus, Greece and Portugal', University of Nicosia, Center for European and International Affairs Working Papers, vol. 7 (2015), 39.

${ }^{36}$ Der Spiegel (staff), 'Russische Schwarzgeldkonten: BND warnt vor Rettungspaket für Zypern', November 3, 2012, http://www.spiegel.de/wirtschaft/soziales/russisches-schwarzgeld-bnd-warnt-vor-rettungspaket-fuerzypern-a-865151.html

${ }^{37}$ Central Bank of Cyprus, Monetary and Financial Statistics, Issue December 2013. https://www.centralbank. cy/en/statistics/money-and-banking-statistics-and-financial-accounts/data/\%C2\%ABmonetary-financialstatistics\%C2\%BB-publication

${ }^{38}$ Eurostat: International investment position - quarterly and annual data, http://appsso.eurostat.ec.europa.eu/nui/ submitViewTableAction.do

${ }^{39}$ Council of Europe-ECRI REPORT ON CYPRUS. (2011), http://www.coe.int/t/dghl/monitoring/ecri/country-bycountry/cyprus/CYP-CbC-IV-2011-020-ENG.pdf
} 
As it has been aptly argued by other scholars too, the "tax haven" and "money laundering" claims had never been a problem for the European Union before, and neither had the banking sector. Back in 2003, when Cyprus was approved to join the EU, no such warning was raised. Likewise, in 2007 when Cyprus joined the Eurozone, no special conditions were levied. Based on an official report published in 2012 by the European Commission, the Cypriot banking sector ranked fourth on the list of potentially endangered banking sectors in the Eurozone. The other countries ahead of Cyprus were Luxembourg (24 times the national GDP), Ireland (eight times) and Malta (7,8 times). Nevertheless, it has been suggested by the Troika to contract the Cypriot banking sector by 50\% until $2018^{40}$.

As George Friedman ${ }^{41}$ also very aptly pointed out, this was an unprecedented solution. Since the global financial crisis of the 1920s, all advanced industrial countries -- and many others -- had been operating on the fundamental principle that deposits in banks were utterly secure. They were not regarded as bonds paying certain interest, whose value would disappear if the bank failed. Deposits were regarded as riskless placements of money, with the risk covered by deposit insurance for smaller deposits, but in practical terms, guaranteed by the national wealth. Furthermore, this move might look like an attempt to seize (illegal) Russian money, but it severely impacted the bank accounts of many Cypriots as well as a sizable amount of legitimate Russian money. EUR100,000 (the upper limit of individual deposits the Central Bank guarantees) is not all that much when you are running a supermarket, a car dealership, or a construction company.

Apart from this, it is well-known in Russia that wealthy Russians and big companies affiliated to Kremlin have deposited their money in Luxembourg or in the Netherlands, as Cyprus has always been perceived as an unstable place to deposit money. Moreover, it seems that Kremlin used the haircut to punish companies preferring to pay their corporate taxes abroad and not within the Russian Federation. There are also rumours that many Russians managed to repatriate their money through the Uniastrum Bank (LLC), which was founded in 199942.

Last but not least, if Cyprus was so important for Russian capital, it would have been exempted from the new regulations designed to repatriate foreign companies back to Russia with promises of a tax amnesty, as introduced by Moscow in late 2014. This was part of Russia's attempts to fight capital flight, which doubled between 2013 and 2014 following the Ukraine crisis and the devaluation of the ruble. Despite the fact that the Cypriot government asked Russia to exempt the island from these laws, or at least enforce them selectively ${ }^{43}$, Cyprus has not been exempted from the Foreign Companies Rules and the new Russian 'de-offshorisation' law, which took effect on 1 January $2015^{44}$.

In posteriori, Eurogroup's policy towards Cyprus in 2013 appears to have been short-sighted. Firstly, if the target was Russia's policies in the Eastern Mediterranean and towards EU and NATO in Syria or else, there has been literally no change at all. On the contrary, Russian military adventures in the Eastern Mediterranean multiplied, Kremlin's involvement in Syria culminated in September 2015 to a military intervention, while Moscow with the annexation of Crimea in 2014 proceed into an unprecedented provocation against the West.

Secondly, in a paradoxical way, what the European leaders engineered, obviously intending to end an economic model fuelled by a flood of cash and "dirty money" from Russia, turned out to backfire. As the bail-in provided that the levied money should be exchanged with equities in the share capital of the levied Cypriot banks, the EU strategy pulled Russia even deeper into Europe's financial system by giving Russian

\footnotetext{
${ }^{40}$ Savvas Katsikides and Georgia Yiangou, 'The Cyprus Banking Crisis: The Bail-in Strategy as a Game Changer for the Too-Big-to-Fail Mentality of the Fractional Reserve Banking System', in: Society and Economics in Europe, eds. S. Katsikides and H. Hanappi (Switzerland: Springer International Publishing, 2016) 209-210.

${ }^{41}$ G. Friedman, 'Europe's Disturbing Precedent in the Cyprus Bailout', Stratfor analysis March 26, 2013.

${ }^{42}$ Personal communication with Yuri Kvashnin, Head of Section of the EU Studies of the Institute of World Economy and International Relations of the Russian Academy of Sciences (Moscow, 3 September 2015).

${ }^{43}$ Stratfor, "Amid Sanctions Battle, Russia Courts Cyprus", Feb 27, 2015.

44 The main innovation of the new law is the disclosure and taxation of foreign companies controlled by Russian tax residents. Under the new law taxpayers are required to notify the tax authorities of any holding of more than 10 percent in a foreign legal entity, and of any interest in a foreign structure that does not involve the formation of a legal entity (whether as a beneficiary or in any other capacity). Although Cyprus had a comprehensive double taxation agreement with Russia, which includes up-to-date information exchange arrangements, the Cyprus corporate tax rate of 12.5 per cent was below the effective tax rate (generally 15 per cent) required for exemption on the basis of the effective tax rate. Neocleous op. cit., 610-613.
} 
deposit-owners ${ }^{45}$ majority ownership, at least on paper, of the Bank of Cyprus the country's oldest, biggest, and most important financial institution.

Thirdly, if the levy on the Cypriot banks was part of the EU's battle against money laundering, this policy clearly backfired, as the Russian money merely changed the routes ending up in other banks like Danske Bank, resulting in the biggest money-laundering scandal in EU history. ${ }^{46}$

- Meanwhile and probably due to the stricter regulations adopted by Moscow against Russian companies investing abroad, as well as the EU regulations against money laundering, Russian capital has been flowing out of Cyprus. According to various estimates that have circulated in the Cypriot press, between 2015 and February 2019, about EUR5 billion in Russian depositors' bank accounts were withdrawn. According to data released by Cyprus' Central Bank, deposits of Russian origin stood in February 2019 at EUR6,867 millions ${ }^{47}$. According to Eurostat, the total deposit taking corporations except the Central Bank coming from Russia had decreased to EUR4,115 million o in the fourth quarter of $2018^{48}$.

\section{References:}

1. Abushov, Kavus: Professor at Azerbaijani Diplomatic Academy-ADA, Expert on Russia (Baku, 22 August 2017).

2. Kvashnin, Yuri: (Head of Section of the EU Studies of the Institute of World Economy and International Relations of the Russian Academy of Sciences) (Moscow, 3 September 2015)

3. Mavrogiannis, Andreas: Cypriot Diplomat and special negotiator of the Republic Cyprus in the intercommunal talks since 2013 (electronically, August 2017).

4. Mor Amit: Energy Expert-Professor for Energy economics and geopolitics (September 2018, Hertzliya, Israel).

5. Adams Th. and Cottrell A. (1968) Cyprus between East and West. Baltimore: The John Hopkins University Press.

6. Alterman J. B., Conley H. A., Malka H., Ruy D. (2018) Restoring the Eastern Mediterranean as a U.S. Strategic Anchor', Center for Strategic and International Studies (CSIS) report. New York et. al.: Rohman and Littlefield.

7. Auswärtiges Amt der Bundesrepublik (1987) Europäische Politische Zusammenarbeit. Dokumentation. Bonn: Auswärtiges Amt der Bundesrepublik.

8. Bechev D. (2017) Rival power. Russia's influence in Southeast Europe. New Haven and London: Yale University.

9. Central Bank of Cyprus, Monetary and Financial Statistics, Issue March 2013 and March 2019.

10. Central Bank of Cyprus (2002), Monetary Policy Report, http://www.centralbank. gov.cy/nqcontent.cfm?a id=10364\&lang=en.

11. Central Bank of Cyprus, Monetary and Financial Statistics, Issues December 2013 and February 2019.

12. Council of Europe-ECRI Report on Cyprus, (2011), http://www.coe.int/t/dghl/monitoring/ecri/country-by-country/ cyprus/CYP-CbC-IV-2011-020-ENG.pdf

13. Christou G. (2004) The European Union and Enlargement. The Case of Cyprus. New York: Palgrave Macmillan.

14. Delanoe I. (2013) 'Cyprus, a Russian foothold in the changing Eastern Mediterranean', Middle East Review of International Affairs, Vol. 17, No. 2, pp. 84-93.

15. Der Spiegel (staff) (November 3, 2012) 'Russische Schwarzgeldkonten: BND warnt vor Rettungspaket für Zypern', http:// www.spiegel.de/wirtschaft/soziales/russisches-schwarzgeld-bnd-warnt-vor-rettungspaket-fuer-zypern-a-865151.html

16. Dennison S. \& Pardijsp D. (June 2016), "The world according to Europe's insurgent parties: Putin, migration and people power", European Council on Foreign Relations Paper.

17. European Parliament Press Releases (February 27, 2019), 'Tax crimes: special committee calls for a European financial police force', http://www.europarl.europa.eu/news/en/press-room/20190225IPR28727/tax-crimes-specialcommittee-calls-for-a-european-financial-police-force.

18. Eurostat: International investment position - quarterly and annual data. http://appsso.eurostat.ec.europa.eu/nui/ submitViewTableAction.do

\footnotetext{
${ }^{45}$ According confidential information the Author collected in Moscow, some of the biggest stakeholders in the Cypriot Banks are the Renova Group owned by Viktor Vekselberg and Vladimir Strzhalkovskiy who are supposed to be Putin's confidante.

${ }^{46}$ Rettman, op. cit.

${ }^{47}$ Central Bank of Cyprus, Monetary and Financial Statistics, Issue March 2019.

${ }^{48}$ Eurostat, International investment position - quarterly and annual data. http://appsso.eurostat.ec.europa.eu/nui/ submitViewTableAction.do
} 
19. Fabry N. and Zeghni S. (2002), 'Foreign direct investment in Russia: How the investment climate matters', Communist and Post-Communist Studies, Vol. 35, No. 3, pp. 289-303.

20. Friedman G. (March 26, 2013), 'Europe's Disturbing Precedent in the Cyprus Bailout', Stratfor analysis, https:// worldview.stratfor.com/article/europes-disturbing-precedent-cyprus-bailout

21. Kappis V. (2016) 'The Bear Learns to Swim: Russia's Re-emergence in the Mediterranean', Eastern Mediterranean Geopolitical Review, Vol. 2, pp. 29-49.

22. Katsikides Savvas and Yiangou Georgia (2016), 'The Cyprus Banking Crisis: The Bail-in Strategy as a Game Changer for the Too-Big-to-Fail Mentality of the Fractional Reserve Banking System', in Society and Economics in Europe, eds. S. Katsikides and H. Hanappi. Switzerland: Springer International Publishing: 207-216.

23. Kaveshnikov N. (2017) 'Energy security in Mogherini' s strategy: Conclusions for Russia', in: The EU global strategy: implications for Russia, ed. Olga Potemkina. Moscow: Institute of Europe, Russian Academy of Sciences/Egmont. The Royal Institute for International Relations: 52-62.

24. Ker-Lindsay J. (2011) 'Membership and Foreign Policy', in: An Island in Europe. The EU and the Transformation of Cyprus J. Ker-Lindsay, H. Faustmann H. and F. Mullen. London and New York: Tauris: 112-133.

25. Liuhto K. and Majuri S. (2014) 'Outward foreign direct investment from Russia: A literature review', Journal of EastWest Business, Vol. 20, No. 4, pp. 198-224.

26. Liuhto K. (2001) 'Russian gas and oil giants conquer markets in the West: Evidence on the internationalization of Gazprom and LUKoil', Journal of East-West Business, Vol.7, No. 3, pp. 31-72.

27. Manuel J., Pérez T. (2017) 'Russia in the Eastern Mediterranean: a counterweight to the West?', in: War in peacetime Russia's strategy on NATO's Eastern and Southern Flanks, eds. Nicolás De Pedro and Francis Ghilès. Barcelona: Barcelona Institute for International Affairs: 45-51.

28. Melakopides C. (2016) Russia-Cyprus Relations. A Pragmatic Idealist Perspective. Basingstoke, Hampshire: Palgrave Macmillan.

29. Neocleous E. (2015) 'The potential impact of Russian de-offshorization legislation on Cyprus holding and finance structures', Trusts \& Trustees, Vol. 21, No. 6, pp. 610-613.

30. Pelto E., Vahtra P., Liuhto K. (2003) Cyprus Investment Flows to Central and Eastern Europe - Russia's Direct and Indirect Investments via Cyprus to CEE. Turun Kauppakorkeakoulu: Turku School of Economics and Business Administration.

31. Pierini M. (3 December, 2018) 'Russia's Gas Strategy Gets Help From Turkey', Carnegie Endowment, https:// carnegieeurope.eu/strategiceurope/77855

32. Phidias P. (2002) The Role of Cyprus in Inward Investment in Russia, Central and Eastern Europe. Cyprus: PricewaterhouseCoopers.

33. Razumovskaya O. (Feb. 25, 2015) 'Cyprus signs deal to let Russian navy ships stop at its ports', Wall Street Journal, http://www.wsj.com/articles/putin-highlights-closer-russia-cyprus-ties-1424882012

34. Rettman A. (September 2018) 'Cyprus: Russia's EU weak link?, EU Observer', https://euobserver.com/justice/14292025.

35. Stefanini, S. (February 17, 2017) 'Cyprus fears Russia could wreck reunification', Politiko, http://www.politico.eu/ article/cyprus-fears-russia-could-wreck-reunification/

36. Stergiou A. (2007) 'Soviet policy toward Cyprus, Cyprus Review', Vol.19, No. 2, pp. 83-106.

37. Stergiou A. (2016) 'Euroscepticism in Cyprus', in: European Integration and New Anti-Europeanism. The 2014 European Election and New Anti-European Forces in Southern, Northern and Eastern Europe (volume 2), eds. Patrick Moreau \& Birte Wassenberg. Stuttgart: Franz Steiner: 55-66.

38. Stergiou A. (2017) "Russian Federation's Foreign Policy in the Eastern Mediterranean Since the End of Cold War: Geoeconomic and Geopolitical Parameters", in: Conflict \& Prosperity, Geopolitics and Energy in the Eastern Mediterranean, eds. Andreas Stergiou, Kivanc Ulusoy and Menahem Blondheim. New York-Jerusalem: Konrad-Adenauer-Stiftung - The Harry S. Truman Research Institute for the Advancement of Peace Hebrew University of Jerusalem in cooperation with Israel Academic Press: 77-111.

39. Stergiou A. (2019) 'The History of Cyprus', in 'The Middle East and North Africa', ed. Christopher Matthews. 65th edition. London and New York, Routledge: 155-162.

40. Stratfor (February 27, 2015) "Amid Sanctions Battle, Russia Courts Cyprus", https://worldview.stratfor.com/article/ amid-sanctions-battle-russia-courts-cyprus

41. The National Herald (Staff) (September 4, 2018) 'White House 1974 Cyprus Meeting: Kissinger Backed Turkey Over Greece', https://www.thenationalherald.com/212131/white-house-1974-cyprus-meeting-kissinger-backed-turkeyover-greece/

42. Tilliros P. (2015) 'Causes and impact of the MOYs on the economies of Cyprus, Greece and Portugal', University of Nicosia, Center for European and International Affairs Working Papers, vol. 7.

43. Tastan K. and Kutschka T. (2019) 'The Implications of Eastern Mediterranean Gas for Turkey', The German Marshall Fund of the United States paper, no. 7. 
44. Tsardanidis Ch. (1984) 'The European Community and the Cyprus crisis of 1974', Revue Hellénique de droit international, Vol. 5, pp. 185-207. 45. Tsardanidis Ch. and Nicolaou Y. (1998) 'Cyprus Foreign and Security Policy: Options and Challenges', in: The Foreign Policies of the European Union's Mediterranean States and Applicant Countries in the 1990s, eds. S. Stavridis, T. Veremis, T. Couloumbis, N. Waites. Basingsstoke, Hampshire, University of Reading European and International Studies: 171-194.

46. Umbach F. (March 18, 2019) 'The future of LNG for Europe', Geopolitical Intelligence Service, https://www. gisreportsonline.com/the-future-of-Ing-for-europe,energy,2829,report.html

47. US Department of State (August 28, 1998), Daily Press Briefing, Clinton Presidential Records, declassified documents, Memorandum of Telephone Conversation between Bill Clinton and Tony Blair, 11 December 1998. https://www. clintonlibrary.gov/

48. Zonova T. (2015) 'Mediterranean trend in the Russia's foreign policy', Rivista di Studi Politici Internazionali, Vol. 82, No. 4, pp. 521-529.

\section{ЕС, РОССИЯ И КИПР}

В последние годы российско-кипрские отношения являются очень актуальной темой для политиков, ученых и журналистов ЕС, занимающихся международными отношениями России, Юго-Восточной Европы и Восточного Средиземноморья. Благодаря этому глубокому интересу были исследованы многие неизвестные стороны темы. Тем не менее, большинство аналитических исследований следовало определенной модели, которая не всегда соответствовала действительности. Хотя Кипр занимает исключительное место в российской внешней политике, интерес России к кипрским экономическим и политическим вопросам, однако, в некоторых случаях был переоценен. В результате по разным геополитическим и геоэкономическим причинам остров был втянут $b$ политические и экономические отношения НАТО-ЕС-Россия, возникшие $b$ последние десятилетия, и запла-

\section{Ключевые слова:}

Европейский Союз, Еврогруппа, Кипрские банки, Кремль, газовое месторождение East $\mathrm{Med}$, оборонное сотрудничество тил за это высокую иену. На этом фоне можно утверждать, что решения Еврогруппы $b$ отнощении кипрских банков в марте 2013 года были необоснованными и ложными и $b$ конечном итоге не достигли иелей, которые они намеревались достичь. В статье также опровергается мнение, что Москва заинтересована в нефтегазовом месторождении EastMed из-за его значения b политике диверсиоикации поставок энергоносителей $b$ EC. Российские компании, похоже, не выступают против различных проектов, направленных на разработку ресурсов месторождения EastMed, поскольку они не рассматривают газ этого месторождения как угрозу своим экономическим интересам.

Андреас Стергиу, доцент кафедры экономики, Университет Фессалии (Греция).

Keywords:

European Union, Eurogroup, Cypriot Banks, Kremlin, East Med Gas, Defence Cooperation 